\title{
A Study on the Influence of Personal Characteristics of Youth Employment on the Preparation for Turnover: Focused on the adjustment effect of experience in failing to get jobs
}

\author{
Jong-Jin KIM ${ }^{1}$, Kyung-Ho UM ${ }^{2}$
}

Received: June 15, 2020. Revised: June 30, 2020. Accepted: July 05, 2020

\begin{abstract}
Purpose: In this study, we would like to confirm that the transfer of young workers may be a means of enhancing their internal satisfaction, not to get a better job, by setting work-related characteristics that are highly relevant to job-related factors. Research design, data, and methodology: In this study, preparation for turnover was set as dependent variables to identify factors related to the turnover of young people, and the type of business, employment type, debt status, job satisfaction, job difficulty compared to education level, job difficulty, job degree, job major agreement, debt status, and other demographic social characteristics were selected as independent variables. Results: The characteristics related to personal criteria in job-seeking process were significant in the form of business, employment type, job satisfaction, work difficulty compared to the level of education, work difficulty compared to the level of technology, job major matching, and debt status. Conclusions: This study confirmed that young people's turnover may not simply be a means to get a better job, but to increase satisfaction in the internal aspects of their jobs, and that for young people, a job is an important development process that represents their identity and needs to be approached from a life-cycle perspective.
\end{abstract}

Keywords : Youth Employment, Personal Criteria In Job-Seeking Process, Experience of Failing to get Jobs, Preparation for Turnover

JEL Classification Code : E21, J14, K32

\section{Introduction}

Since the global economic downturn and financial crisis, unemployment among young people has become a serious social problem in many countries. According to the European Union Statistics Office (Eurostat), European youth unemployment rate reached $15.8 \%$ at the end of 2020 and youth unemployment has reached about 4.8 million.

In the case of the United States, the youth unemployment rate reached a record high of 15.8 percent in May 2020 and

\footnotetext{
1 First Author: Ph.D. researcher, Manager of Social Economic UNHABITAT, Korea. Tel: +82-2-761-8001. Email: 2001j2k@hanmail.net.

2 Corresponding Author Professor, Department of Social Welfare, Kaya University, Korea. Tel: +82-53-766-5345. Email: ukyungho@naver.com

(c) Copyright: The Author(s)

This is an Open Access article distributed under the terms of the Creative Commons Attribution Non-Commercial License (https://creativecommons.org/licenses/by-nc/4.0/) which permits unrestricted non-commercial use, distribution, and reproduction in any medium, provided the original work is properly cited.
}

for Korea, it has reached 10.2 percent in May 2020. Youth unemployment is not limited to the individual concerned, but also has various negative effects on society as a whole. Youth unemployment, which first enters the labor market, causes a setback and self-esteem problems for the parties concerned, and the longer the unemployment period, the worse the physical and mental health conditions gets. In general, early unemployment can have a long-term negative effect on individuals because they are more likely to be trained in their youth, more adaptable, and can affect behavior patterns created in their youth for the rest of their lives. In addition, unemployment among young people will not only lead to economic poverty but also to social isolation and alienation, leading to the entrenchment of new classes, and the continuation of unemployment will delay the marriage period and cause problems of decreasing birth rate, adversely affecting the overall structure of society. This will have a negative effect not only on individuals but also on the potential growth potential of society and the future national competitiveness(McKee, Song, Wanberg, \& Kinicki , 2005). 
However, despite the high unemployment rate, young people often change jobs frequently, not setting down after they get a job. While changing jobs has a positive effect in that it can increase welfare and find a job that is more suitable for one's own, it also has a negative effect that it can eventually lead to career loss. A study focused on the development process of young people argued that changing jobs was an important issue for young people in their early career years, and that voluntary changing job was a positive process for finding suitable jobs. On the other hand, others argue that frequent turnover has a negative impact on enhancing career and expertise because young people have relatively little job experience(Song, Wangerg, Niu, \& Xie, 2006).

Moreover, although there are conflicting claims against youth turnover due to the stress of failure in employment, most empirical studies sought to draw conclusions based on the assumption of job insecurity, and studies were conducted on the relationship between unstable employment conditions and poverty, such as non-regular workers and job experience. Such prior research excludes the possibility that turnover may be a voluntary job search process for young people, and it can be said that this does not take into account the cyclical characteristics of life(Wanberg, Kanfer, \& Banas, 2000).

In this study, we will use representative data to determine what factors are related to the preparation for the young people's preparation for turnover.

\section{Theoretical backgrounds}

\subsection{Preparing for turnover}

Changing job means moving boundaries in a broad sense as a member of the social system. Many studies have been done because turnover affects not only the parties involved in the turnover but also the organizations concerned. With regard to changing jobs, The turnover can have a variety of effects, positive effects such as the spread of new technologies, the promotion of change, and negative effects such as the occurrence of training costs and the loss of highquality human resources, explaining that turnover can have various effects (Mobley, 1982).

In Korea, $60.8 \%$ of university graduates quit their first job, and the average length of service at their first job is one year and 2.8 months, which is very short. Young people engage in various activities such as finding jobs suitable for them through voluntary turnover compared to middle-aged people, which can be seen as a result of low opportunity costs as they have relatively little career experience. The turnover of these young people was found to be affected by various key-figures(Price, 2001).

First, the related factors can be broadly divided into general characteristics of individual and job-related factors. In relation to general characteristics, existing previous studies dealt with age, educational standards, marital status, etc. In the case of age and turnover, the desire to change jobs tends to decrease as the age increases. and this seems to be due to the desire to do something stable and the opportunity to change jobs decreased. However, as age is highly correlated with variables such as education standards, it should be put into the model together and analyzed rather than used as a single variable(Topel \& Ward, 1992).

In addition, depending on the level of education, the higher the academic ability, the higher the level of expectations, the more likely the person is not satisfied with his or her current job environment, and the higher the educated, the more opportunities he or she may have to change jobs. Occupational status is in the form of employment, such as full-time and non-regular workers, divided into regular workers, temporary workers and day-today workers and can be described as job security. As working conditions such as welfare and wages vary depending on the size of the business entity, the desire to change jobs is expected to increase further if the gap is felt accordingly(Saari \& Judge, 2004)

\subsection{Personal criteria in job-seeking process}

Personal criteria in job-seeking process is the criteria for the attributes that that one has to prepare for from the standpoint of a job seeker. Therefore, it is defined as the minimum value of the attribute, which is an important consideration in deciding whether to work or not. In other words, if a job fails to meet the personal criteria of a job seeker, it will be rejected(Hahn, 2005).

At this point, the most important factor is the wage level. In addition, various factors such as the location of the workplace, the size of the company, and whether it is in the public sector have a significant impact on determining the personal criteria in job-seeking process. We cannot help but look at the personal criteria in job-seeking process among the variables of the youth's entry into the labor market and failure to enter the labor market. In order to find a good job, you can either form a personal criteria before entering the labor market, or you can continue to look for a job afterwards. In this regard, we looked at job level variables based on prior research, focusing on personal characteristics, business characteristics, and relationships with people(Dicker, Roznowski, \& Harrison, 1996).

In the previous research, personal criteria in job-seeking process was mainly analyzed, and besides economic compensation, there is a lack of systematic analysis of factors affecting personal criteria in job-seeking process. For example, if you focus only on economic compensation, it's more advantageous for you to work for a large company 
than for a Public official of Grade 9. However, in terms of employment stability, it is possible to prefer being public official than working for large corporations(Gardecki \& Neumark, 1998).

There are two cases in which a reserved wage ends the period of a job-seeking activity with the minimum wage to be paid to provide workers with labor: One is to give up job hunting and become economically inactive, and the other is to be employed, which occurs when the proposed wage is higher than the retained wages.

Labor economics suggests that when workers give up leisure and provide work, the wage rate should be high enough to offset the marginal costs of providing labor. In addition, the traditional job search model explains that it is the best strategy for job seekers to set their own retained wages and then accept proposals only when the offered employment wage is higher than the retained wages, and continue to search without admitting employment when it is lower. Labor economics also argues that the wage rate is the most important variable for determining the employment of workers. In fact, however, various factors such as employment stability and the size and location of a company can be used as criteria for determining employment(Sanders, Nee, \& Sernau, 2002).

In other words, it is not enough to explain the phenomenon of young workers' turnover only by the existing "eye-point theory" of re-employment in good jobs by building a career in the labor market due to poor working conditions and poor wage levels(Behtoui, 2004).

Therefore, in this study, we would like to confirm that it may be a means to increase the satisfaction of young workers, rather than to get a better job, by setting up workrelated characteristics that are highly correlated with jobrelated factors as main variables.

\subsection{Experience of failing to get jobs}

Experience of failing to get employed is a condition that destroys physical, psychological and social equilibrium due to problems related to employment, which makes people feel threatened, nervous, and uneasy. In addition, it is affected by factors such as uncertainty about the future, lack of clarity, and lack of job information(Wanberg, Glomb, Song, \& Sorenson, 2005).

Individuals who have failed to find a job will experience repeated failures while learning lethargy, thereby damaging their sense of self-effectiveness. Such lethargy is characterized by reduced anxiety, depression, passiveness, decreased aggression, decreased problem solving and lack of patience for action. Therefore, failure to find a job leads to a feeling of apathy, depression, hostility, frustration, and suicidal urge. In the end, this will be a generalization of negative views and frustrations about the future related to
jobs(Saari \& Judge, 2004).

People who experience job failures have different levels of helplessness, loss and frustration, but ultimately lose their motivation, resulting in negative results. When a state of exhaustion is reached, it goes through emotional, psychological and physical stages in the process of enthusiasm, stagnation, frustration and apathy, which have negative consequences for itself and others. Young job seekers who experience frustration caused by failing to get jobs due to repeated failing gradually lose their ideals, energy, purpose, and interest through this series of processes. Therefore, the longer the process lasts, the more negative it affects the life and health of the individual(Hahn, 2005).

Failing to get jobs have a negative impact not only on individuals but also on society.

The setbacks and failures experienced in the job search process become a turning point in life, and the loss of gross domestic product due to prolonged unemployment and increasing idle human resources will bring about a midlong-term economic downturn(Portes \& Landolt, 2000).

In addition, the social deviant behavior of job seekers who have lost their motivation to work and the possibility of crime, the craze for lottery tickets, and the "let's try it out" are factors causing serious social problems, such as the surge in individual bankruptcies and credit delinquents caused by uncontrolled consumption(Law, Wong, \& Song, 2004).

\section{Research and analysis}

\subsection{Research subjects and collecting data}

In order to analyze various factors related to the preparation of young people for turnover, this study utilized the Youth Panel Survey data organized by the Korea Employment Information Service.

The Youth Panel Survey aims to collect basic data that reflects the personal and social factors of the youth group, establishing employment policies and developing related research fields of young people in order to resolve youth unemployment. This is the nation's first individual panel survey, a longitudinal survey that tracks and examines samples built for people aged 15 to 34 every year. In this study, data from 2007-2018 were used for the 1-12nd year of YP2007. The final study subjects were 4,230 samples of raw materials, excluding students. Employment refers to those who are not students and have worked for income in the past week. Specifically, they are not students, but those who go to work all day, those who work for more than 18 hours a week, those who are expected to graduate in advance, and those who have taken a leave of absence from school and got a job instead of a part-time job. The construction of 
YP2007 focused on gathering information on past experience for each theme, and based on this, the following follow-up survey focused on gathering information on matters that have changed in the past year.

The personal type questionnaire was conducted separately for middle and high school students, university students, graduate students, workers, and unemployed people.

To that end, the computer-based personal interview system was implemented so that only the surveys for that type could be conducted. The youth panel survey contains a wide range of data on the transition process from school to job and the labor market path for young people, and provides insight into various aspects related to youth as well as education, training and job security, making it a suitable resource for the purpose of this research.

\subsection{Operational definition of variables and measurement tools}

In this study, preparation for turnover was set as dependent variables to identify factors related to the turnover of young people, and demographic and social characteristics were defined as independent variables, such as the form of business, employment, debt status, job satisfaction, job difficulty for the education level, job difficulty for the technical level, job matching for a degree, debt status, and so on..

\subsubsection{Independent Variable: Personal criteria in job-seeking process}

Independent variables can be broadly divided into demographic and social characteristics and characteristics of employment eye level. The demographic characteristics considered age, marital status, final educational background and religious status. Marriage was divided into two groups: married and unmarried(including separation, divorce and death).

Final education was divided into high school graduates and junior college graduates and college graduates. Variables indicating personal criteria in job-seeking process characteristics were divided into business type, employment type, debt status, job satisfaction level, work difficulty compared to education level, work difficulty compared to technology level, major agreement of work, and debt status.

\subsubsection{Dependent Variables : Turnover intention}

A turnover intention can be defined as an intention to voluntarily leave the organization and is a cognitive state of the action to change jobs. In this study, they were measured by answers to questions about the exact preparation for changing jobs that were not intended to be actionable, and divided into "prepared" and "not prepared."

\subsubsection{Moderator variable: Experience of failing to get employed}

Failing to get employed can define failure or frustration in the job search process and is a cognitive state of failure experience. In this study, the answer to the experience of failing to get jobs was measured and divided into 'yes' and 'no'.

\subsection{Data analysis}

Frequency analysis and technical statistical analysis were performed to grasp general characteristics of the target subject. Frequency and percentages are presented for discrete variables as statistic quantities, and average and standard deviation are presented for continuous variables. (Kim, 2016)

Hierarchical regression using the Generalized Estimating Equations (GEE) method was used to verify differences in job preparation according to demographic and work-related characteristics and to analyze the relevant factors of job preparation, and the adjustment variables were analyzed for verification of adjustment variables. To evaluate the influence of each factor, a one-variate analysis was performed sequentially, and a multivariate analysis, a complete research model that corrected the influence of the other factors, presented the odds ratio (OR) and 95\% confidence intervals as statistics. Stata/MP version 14.2 (StataCorp, College Station, TX, USA) was used for all statistical processing, and the significance level was set at 5\% on both sides.

\section{Conclusions}

\subsection{Hierarchical analysis.}

This study carried out a graded regression analysis to understand whether or not variables, including demographic and employment line characteristic variables, are affecting job- change preparations Table 1. First, a step-by-step input method was used to exclude from the analysis the possible multicollinearity variables among the demographic and sociological characteristics variables (Kim, 2014).

In Model 1, only the demographic and sociological variables that are control variables were included in the analysis and a regression analysis was performed.

Overall, the model described the youth's job-changing preparation variable by $15.5 \%$, and the model itself was analyzed to be statistically significant ( $\mathrm{p}<.01)$. Model 2 is a model that introduces new job seekers to the demographic and sociological changes of Model 1. The model described youth turnover preparation variables $21.2 \%$ and found the model to be significant $(\mathrm{p}<.01)$. 
Table 1: Adequacy of job preparation analysis for young people

\begin{tabular}{|c|c|c|}
\hline Variable factor & Model1 & Model2 \\
\hline $\mathrm{R}=$ & $\mathrm{R}=.271$ & $\mathrm{R}=.349$ \\
$\mathrm{R}^{2}=$ & $\mathrm{R}^{2}=.155$ & $\mathrm{R}^{2}=.212$ \\
Modified $\mathrm{R}^{2}=$ & Modified $\mathrm{R}^{2}=.151$ & Modified $\mathrm{R}^{2}=.199$ \\
$\mathrm{~F}=$ & $\mathrm{F}=5.332^{\star *}, \mathrm{p}=.000$ & $\mathrm{~F}=25.268^{\star *}, \mathrm{p}=.000$ \\
Durbin-Watson $=$ & Durbin-Watson $=$ & Durbin-Watson $=$ \\
& 1.808 & 1.808 \\
\hline
\end{tabular}

Model 1 included only demographic sociological variables that are control variants and conducted regression analysis. Overall, among the demographic sociological variables, the variables that significantly affect the preparation for turnover were identified as age, final education, and religious status, and marital status was not statistically significant.

Model 2 is a model that adds a variable of personal criteria in job-seeking process characteristics to the demographic and sociological variables of Model 1.

Among the demographic and social variables and personal criteria in job-seeking process variables, the variables that have a significant impact on job preparation were identified as age and health, and religious status were shown to be statistically significant for age and final education. Among the personal criteria in job-seeking process variables, there are business type, employment type, debt status, job satisfaction, job difficulty compared to education level, job difficulty compared to technology level, job major matching and debt status variable

Table 2: Analysis on the Effect of Youth Employment on the Preparing for the Job

\begin{tabular}{|c|c|c|c|c|c|}
\hline \multirow{2}{*}{\multicolumn{2}{|c|}{ Model }} & \multicolumn{2}{|c|}{$\begin{array}{c}\text { Nonstand } \\
\text { ardization factor }\end{array}$} & \multirow{2}{*}{$\begin{array}{c}\begin{array}{c}\text { Standardizing } \\
\text { factor }\end{array} \\
\text { Beta } \\
\end{array}$} & \multirow[t]{2}{*}{$\mathbf{t}$} \\
\hline & & B & Standard error & & \\
\hline \multirow{5}{*}{ Model1 } & (Constant) & 1.923 & .024 & & 80.781 \\
\hline & Age & .002 & .001 & .048 & $2.718^{* *}$ \\
\hline & Final educational background & -.007 & .003 & -.040 & $-2.628^{* * *}$ \\
\hline & Marital status & -.001 & .005 & -.004 & -.204 \\
\hline & Religion & .014 & .006 & .036 & $2.329^{* *}$ \\
\hline \multirow{12}{*}{ Model2 } & (Constant) & 1.638 & .034 & & 47.981 \\
\hline & Age & .002 & .001 & .058 & $3.326^{* * *}$ \\
\hline & Final educational background & -.011 & .003 & -.063 & $-4.045^{\star * *}$ \\
\hline & Marital status & -.001 & .005 & -.003 & -.190 \\
\hline & Religion & .006 & .006 & .016 & $1.062^{*}$ \\
\hline & Business type & -.006 & .003 & -.036 & $-2.364^{* *}$ \\
\hline & Employment type (regular/non-regular) & -.013 & .006 & -.031 & $-2.015^{\star}$ \\
\hline & Job satisfaction & .035 & .004 & .151 & $9.583^{\star * *}$ \\
\hline & Job difficulty compared to level of education & .019 & .006 & .061 & $3.335^{\star * *}$ \\
\hline & Job difficulty compared to technology level & .018 & .006 & .051 & $2.831^{* * *}$ \\
\hline & Degree of concordance with the major of work & .002 & .003 & .014 & $.839^{*}$ \\
\hline & Debt status & .043 & .007 & .098 & $6.326^{*}$ \\
\hline
\end{tabular}

a. Dependent variable: Employment-preparation for turnover: Preparing for turnover ${ }^{*} \mathrm{p}<.05,{ }^{* *} \mathrm{p}<.01,{ }^{* *} \mathrm{p}<.001$.

\subsection{Analysis of the regulation effect on experience of failing to get jobs}

\subsubsection{Analysis of regulation effect between population and socia variables and preparation for change}

Prior to the first analysis, the standardization work between the demographic independent variables and the modulating variables was conducted to analyze the modulating variable relationship through hierarchical regression analysis.

Table 3 is an analysis of the effects of job change preparation on demographic sociological factors, and whether the experience of job failure serves as a modulatory effect during research.

As a result of the analysis, it is necessary to determine whether the explanatory power of the modified $\mathrm{R}^{2}$ has 
increased for the adjustment effect in Table 3. In particular, in order to see the effects of interaction paragraphs in phase 3 , it is important to assess whether $\mathrm{R}^{2}$ has increased the explanatory power of the $\mathrm{R}^{2}$, which shows an increase of $4.4 \%$ for Model 1, 10.3\% for Model 2, and 99.3\% for Model 3, and the change in the significant probability $\mathrm{F}$ was also less than 0.01 .

As a result, among demographic sociological factors, age can be explained to have a controlling effect on the experience of failing to get jobs due to the influence of preparation for leaving the job.

Table 3: Verification of Moderator variable $s$ for age and job preparation

\begin{tabular}{|c|c|c|c|c|c|c|c|c|c|}
\hline \multirow[b]{2}{*}{ Model } & \multirow[b]{2}{*}{$\mathbf{R}$} & \multirow[b]{2}{*}{$\mathbf{R}^{2}$} & \multirow[b]{2}{*}{ Modified $\mathbf{R}^{2}$} & \multirow{2}{*}{$\begin{array}{l}\text { Standard } \\
\text { error of } \\
\text { estimated } \\
\text { value }\end{array}$} & \multicolumn{5}{|c|}{ Statistics Variation } \\
\hline & & & & & $\begin{array}{l}R^{2} \text { change } \\
\text { amount }\end{array}$ & $\begin{array}{c}\text { F change } \\
\text { amount }\end{array}$ & df1 & df2 & $\begin{array}{l}\text { significant } \\
\text { probability } \\
\text { Fvariation }\end{array}$ \\
\hline 1 & $.044^{\mathrm{a}}$ & .002 & .002 & .148 & .002 & 8.021 & 1 & 4228 & .005 \\
\hline 2 & $.103^{b}$ & .011 & .010 & . 147. & .009 & 37.608 & 1 & 4227 & .000 \\
\hline 3 & $.993^{\mathrm{c}}$ & .987 & .987 & .017 & .976 & $\begin{array}{r}314510 \\
.165\end{array}$ & 1 & 4226 & .000 \\
\hline
\end{tabular}

a. Predictive value: (Constant), Age

b. Predictive value: (Constant), Age, Experience of failing to get jobs

c. Predictive value: (Constant), Age, Experience of failing to get jobs, Age* Experience of failing to get jobs

d. Dependent variable: preparation for turnover

The remaining final educational background, marital status, and religious status were found to be insignificant, so it can be analyzed as having no Regulation effect

\subsubsection{Analysis of regulation effect between employment eye Level variables and Job preparation \\ Prior to the analysis, the analysis of the adjustment} variable relationship through hierarchical regression analysis was conducted through the standardization of variables between the independent variables and the variables at the job level of adjustment.

Table 4 below is an analysis of whether experience of failing to get jobs acts as a control effect during a study on the impact of job placement preparation among job-level variables.

Analysis results Table 4 have increased the explanatory power of the modified $\mathrm{R}^{2}$ for regulatory effects. In particular, in order to see the impact of the interaction section in the third stage, it was evaluated whether or not the explanatory power of $\mathrm{R}^{2}$ was increased, but it was found that $\mathrm{R}^{2}$ gradually increased to $6 \%$ for model $1,11.5 \%$ for model 2 , and $12.3 \%$ for model 3 , and the amount of change in significant probability $\mathrm{F}$ was less than 0.01 .

As a result, it can be explained that among the job-level variables, the employment type variable has a controlling effect on job-hunting failure experience in the relationship of job-preparation.

Table 4: Verification of Moderator variable s for solid form and preparation for turnover

\begin{tabular}{|c|c|c|c|c|c|c|c|c|c|}
\hline \multirow[b]{2}{*}{ Model } & \multirow[b]{2}{*}{$\mathbf{R}$} & \multirow[b]{2}{*}{$\mathbf{R}^{2}$} & \multirow[b]{2}{*}{ Modified $\mathbf{R}^{2}$} & \multirow[b]{2}{*}{$\begin{array}{l}\text { Standard error of } \\
\text { estimated value }\end{array}$} & \multicolumn{5}{|c|}{ Statistics Variation } \\
\hline & & & & & $\begin{array}{l}R^{2} \text { change } \\
\text { amount }\end{array}$ & $\begin{array}{l}\text { F change } \\
\text { amount }\end{array}$ & df1 & df2 & $\begin{array}{l}\text { significant } \\
\text { probability } \\
\text { Fvariation }\end{array}$ \\
\hline 1 & $.060^{\mathrm{a}}$ & .004 & .003 & .148 & .004 & 15.411 & 1 & 4228 & .000 \\
\hline 2 & $.115^{\mathrm{b}}$ & .013 & .013 & .147 & .010 & 41.164 & 1 & 4227 & .000 \\
\hline 3 & $.123^{\mathrm{c}}$ & .015 & .014 & .147 & .002 & 7.967 & 1 & 4226 & .005 \\
\hline
\end{tabular}

a. Predictive value: (Constant), Employment type

b. Predictive value: (Constant), Employment type, Experience of failing to get jobs

c. Predictive value: (Constant), Employment type, Experience of failing to get jobs, Employment type *Experience of failing to get jobs d. Dependent variable: preparation for turnover

Table 5 below is an analysis of the effects of preparing for a change of job among freaks in job prospects, and whether the experience of failing to find a job during the study works as a regulatory effect. 
As a result of the analysis, it is necessary to determine whether the explanatory power of the modified $\mathrm{R}^{2}$ has increased for the adjustment effect in Table 5. In particular, in order to see the effects of interaction terms in phase 3 , it is important to assess whether $\mathrm{R}^{\mathbf{2}}$ has increased the explanatory power of the interaction term, as shown by the increasing $\mathrm{R}^{2}$ to $18.1 \%$ for Model 1, $19.6 \%$ for Model 2, and $20.5 \%$ for
Model 3, and the significant probability $\mathrm{F}$ change was also less than 0.01 .

As a result, the job satisfaction variable among the personal criteria in job-seeking process variables can be explained that there is a adjustment in job-seeking experience in the relationship of job-seeking preparation.

Table 5: Verification of variables for job satisfaction and job preparation

\begin{tabular}{|c|c|c|c|c|c|c|c|c|c|}
\hline \multirow[b]{2}{*}{ Model } & \multirow[b]{2}{*}{$\mathbf{R}$} & \multirow[b]{2}{*}{$\mathbf{R}^{2}$} & \multirow[b]{2}{*}{ Modified $\mathbf{R}^{2}$} & \multirow[b]{2}{*}{$\begin{array}{l}\text { Standard error of } \\
\text { estimated value }\end{array}$} & \multicolumn{5}{|c|}{ Statistics Variation } \\
\hline & & & & & $\begin{array}{l}\mathrm{R}^{2} \text { change } \\
\text { amount }\end{array}$ & $\begin{array}{l}\text { F change } \\
\text { amount }\end{array}$ & df1 & df2 & $\begin{array}{l}\text { significant } \\
\text { probability } \\
\text { Fvariation }\end{array}$ \\
\hline 1 & $.060^{\mathrm{a}}$ & .033 & .032 & .146 & .033 & 142.676 & 1 & 4228 & .000 \\
\hline 2 & $.115^{b}$ & .039 & .038 & .145 & .006 & 26.096 & 1 & 4227 & .000 \\
\hline 3 & $.123^{c}$ & .042 & .041 & .145 & .003 & 15.018 & 1 & 4226 & .000 \\
\hline
\end{tabular}

a. Predictive value: (Constant), Job satisfaction

b. Predictive value: (Constant), Job satisfaction, Experience of failing to get jobs

c. Predictive value: (Constant), Job satisfaction, Experience of failing to get jobs, Job satisfaction *Experience of failing to get jobs

d. Dependent variable: preparation for turnover

Table 6 below shows whether experience of failing to get jobs acts as a control during a study on the impact of job placement preparation on job difficulty variables compared to education level among job level variables.

As a result of the analysis, it is necessary to determine whether the explanatory power of the modified $\mathrm{R}^{2}$ has increased for the adjustment effect in Table 6. In particular, in order to see the effects of interaction paragraphs in the third phase, it is important to assess whether $\mathrm{R}^{2}$ has increased the explanatory power of $\mathrm{R}^{2}$, which is gradually increased to $13.3 \%$ for Model 1, $16.3 \%$ for Model 2, and $19.0 \%$ for Model 3, and the significant probability F change was also less than 0.01 .

As a result, among the job level variables, the job difficulty variable compared to the level of education can be explained as a result of the adjustment of experience of failing to get jobs in the relationship of job preparation.

Table 6: Verification of variables for job difficulty and job preparation compared to education level

\begin{tabular}{|c|c|c|c|c|c|c|c|c|c|}
\hline \multirow[b]{2}{*}{ Model } & \multirow[b]{2}{*}{$\mathbf{R}$} & \multirow[b]{2}{*}{$\mathbf{R}^{2}$} & \multirow[b]{2}{*}{ Modified $\mathbf{R}^{2}$} & \multirow[b]{2}{*}{$\begin{array}{l}\text { Standard error of } \\
\text { estimated value }\end{array}$} & \multicolumn{5}{|c|}{ Statistics Variation } \\
\hline & & & & & $\begin{array}{l}R^{2} \text { change } \\
\text { amount }\end{array}$ & $\begin{array}{l}\text { F change } \\
\text { amount }\end{array}$ & df1 & df2 & $\begin{array}{l}\text { significant } \\
\text { probability } \\
\text { Fvariation }\end{array}$ \\
\hline 1 & $133^{\mathrm{a}}$ & .018 & .017 & .147 & .018 & 76.113 & 1 & 4228 & .000 \\
\hline 2 & $.163^{\mathrm{b}}$ & .027 & .026 & .146 & .009 & 38.895 & 1 & 4227 & .000 \\
\hline 3 & $.190^{\circ}$ & .036 & .035 & .146 & .009 & 41.325 & 1 & 4226 & .000 \\
\hline
\end{tabular}

a. Predictive value: (Constant), Job difficulty compared to level of education

b. Predictive value: (Constant), Job difficulty compared to level of education, Experience of failing to get jobs

c. Predictive value: (Constant), Job difficulty compared to level of education, Experience of failing to get jobs, Job difficulty compared to level of education *Experience of failing to get jobs

d. Dependent variable: preparation for turnover

Table 7 below analyzes whether experience of failing to get jobs acts as a control during a study on the impact of job placement preparation on job difficulty variables compared to technology level among job level variables.

As a result of the analysis, it is necessary to determine whether the explanatory power of the modified $\mathrm{R}^{2}$ has increased for the adjustment effect in Table 7. In particular, in order to see the effects of interaction terms in phase 3 , it is important to assess whether $\mathrm{R}^{\mathbf{2}}$ has increased the explanatory power of the interaction term, as shown by model 1 at $11.7 \%$, model 2 at $15.2 \%$, and model 3 at $16.9 \%$, and the significant probability $\mathrm{F}$ change was also less than 0.01 . 
As a result, it can be explained that among the job level variables, the job difficulty variable compared to the level of technology is the adjustment of experience in failing to get job in the relationship of job preparation.

Table 7: Verification of variables for job difficulty and job preparation relative to technical level

\begin{tabular}{|c|c|c|c|c|c|c|c|c|c|}
\hline \multirow[b]{2}{*}{ Model } & \multirow[b]{2}{*}{$\mathbf{R}$} & \multirow[b]{2}{*}{$\mathbf{R}^{2}$} & \multirow[b]{2}{*}{ Modified $\mathbf{R}^{2}$} & \multirow[b]{2}{*}{$\begin{array}{l}\text { Standard error of } \\
\text { estimated value }\end{array}$} & \multicolumn{5}{|c|}{ Statistics Variation } \\
\hline & & & & & $\begin{array}{l}R^{2} \text { change } \\
\text { amount }\end{array}$ & $\begin{array}{l}\text { F change } \\
\text { amount }\end{array}$ & df1 & df2 & $\begin{array}{r}\text { significant } \\
\text { probability } \\
\text { Fvariation } \\
\end{array}$ \\
\hline 1 & $.117^{\mathrm{a}}$ & .014 & .014 & .147 & .014 & 59.020 & 1 & 4228 & .000 \\
\hline 2 & $.152^{\mathrm{b}}$ & .023 & .023 & .147 & .009 & 40.154 & 1 & 4227 & .000 \\
\hline 3 & $.169^{\mathrm{c}}$ & .029 & .028 & .146 & .006 & 23.944 & 1 & 4226 & .000 \\
\hline
\end{tabular}

a. Predictive value: (Constant), Job difficulty compared to technology level

b. Predictive value: (Constant), Job difficulty compared to technology leve, Experience of failing to get jobs

c. Predictive value: (Constant), Job difficulty compared to technology leve, Experience of failing to get jobs, Job difficulty compared to technology leve*Experience of failing to get jobs

d. Dependent variable: preparation for turnover

Table 8 Below is an analysis of the effects of job change preparation in job categories, and whether the experience of failure to find a job during research serves as an adjustment effect.

As a result of the analysis, it is necessary to determine whether the explanatory power of the modified $\mathrm{R}^{2}$ has increased for the adjustment effect in Table 8 .

In particular, in order to see the impact of the interaction section in the third stage, it was evaluated whether or not the explanatory power of $\mathrm{R}^{2}$ was increased, but it was found that $\mathrm{R}^{2}$ gradually increased to $6 \%$ for model $1,11.5 \%$ for model 2 , and $12.3 \%$ for model 3 , and the amount of change in significant probability $\mathrm{F}$ was less than 0.01 .

As a result, it can be explained that among the personal criteria in job-seeking process, the job-specific majorconsistent variable has a controlling effect on job-seeking experience in the relationship of job-seeking preparation.

Table 8: Verification of Moderator variable s for major agreement of work and preparation

\begin{tabular}{|c|c|c|c|c|c|c|c|c|c|}
\hline \multirow[b]{2}{*}{ Model } & \multirow[b]{2}{*}{$\mathbf{R}$} & \multirow[b]{2}{*}{$\mathbf{R}^{2}$} & \multirow[b]{2}{*}{ Modified $\mathbf{R}^{2}$} & \multirow[b]{2}{*}{$\begin{array}{l}\text { Standard error of } \\
\text { estimated value }\end{array}$} & \multicolumn{5}{|c|}{ Statistics Variation } \\
\hline & & & & & $\begin{array}{l}\mathbf{R}^{2} \text { change } \\
\text { amount }\end{array}$ & $\begin{array}{c}\text { F change } \\
\text { amount }\end{array}$ & df1 & df2 & $\begin{array}{r}\text { significant } \\
\text { probability } \\
\text { Fvariation }\end{array}$ \\
\hline 1 & $.117^{\mathrm{a}}$ & .014 & .014 & .147 & .014 & 59.020 & 1 & 4228 & .000 \\
\hline 2 & $.152^{\mathrm{b}}$ & .023 & .023 & .147 & .009 & 40.154 & 1 & 4227 & .000 \\
\hline 3 & $.169^{\mathrm{c}}$ & .029 & .028 & .146 & .006 & 23.944 & 1 & 4226 & .000 \\
\hline
\end{tabular}

a. Predictive value: (Constant), Degree of concordance with the major of work

b. Predictive value: (Constant), Degree of concordance with the major of work, Experience of failing to get jobs

c. Predictive value: (Constant), Degree of concordance with the major of work, Experience of failing to get jobs, Degree of concordance with the major of work *Experience of failing to get jobs

d. Dependent variable: preparation for turnover

\section{Conclusions}

\subsection{Research results}

In this study, we analyzed the factors associated with the preparation of young people for turnover using the data for 2018 which is the 1-12th year of the Youth Panel. In particular, it was intended to conduct an analysis of the exact preparation of the transfer, rather than the cognitive state of giving up being a member of the organization and leaving the current job.

The independent variables selected demographic and job-related characteristics. According to the analysis, the age, final education, and religious status were significant in the demographic characteristics, and the characteristics related to personal criteria in job-seeking process were significant in the form of business, employment type, job satisfaction, work difficulty compared to the level of education, work difficulty compared to the level of technology, job major 
matching, and debt status.

In terms of demographic characteristics, the older the person was, the less likely they were to prepare for a job change. It is a time when young people actively seek jobs than other age groups, but the older they are, the more they can be explained by the responsibility of family support, the difficulty of finding suitable alternative jobs due to the accumulation of corporate special skills, etc. This shows that factors affecting turnover can gradually vary depending on age and career. In the case of higher educational background, the more likely it was to prepare for a change of job, which was similar to the results of a prior study that a higher level of education was a variable that raised the desire to change jobs. The higher the educational background, the higher the level of expectations, so it can be seen that they are actively pursuing employment.

According to the personal criteria in job-seeking process of young workers, non-regular workers are more prepared to change jobs than regular workers, depending on the type of employment. According to the recent employment patterns of the first jobs, 52.4 percent of regular workers are employed, which is quite high, as is 79.1 percent of nonregular workers.

This was contrary to previous research, which showed that the intention to leave the workplace was higher due to the difference in compensation and treatment provided by the workplace, such as employment and welfare.

However, such results can be partly explained by previous research that the internal aspects of job-related factors, such as salary and promotion, have a greater impact on those with early college graduates. In addition, the type of business showed that the larger the company, the less preparing for the job, and the smaller the company, the more preparing for the job. This seems to be the case because large companies have higher wages and benefits, as in previous employment patterns.

Among the characteristics of young workers' employment standards, if education and technology levels are inconsistent with their work, chances were high that they would prepare for the change of jobs. If the level of education and technology is not suitable for the job, the job satisfaction will be reduced and the job will be changed.

This is similar to a study that increases job satisfaction and lowers the intention of leaving the job when the level of individual matches the level of job when dividing job suitability into major, educational and technical levels. The less satisfied with the pursuit of self-development, the more likely it was to prepare for the change, such as selfdevelopment, which reduces the intention of the change and allows the person to immerse himself in the organization, in the same context as early experienced people value career development and development potential.

In this study, the types of jobs that are currently employed were distinguished, but the quality of the jobs (personal welfare, size of business, etc.) was analyzed without distinguishing them, so it is necessary to be careful to generalize the results into all types of job preparation for young people. In addition, it was difficult to determine the causes and consequences of voluntary and involuntary turnover and the time-honored relationship.

The analysis of the adjustment effect of experience of failing to get jobs is as follows. First, the analysis of the adjustment effect on experience of failing to get jobs showed that age is a significant variable between demographic and sociological variables and the relationship of influence between job preparation. The younger you are, the likely to prepare for a job change, but fewer people have failed to find a job than people who have.

Secondly, the personal criteria in job-seeking process variables were analyzed to have an effect of controlling experience of failing to get jobs between job placement preparation and job loss preparation, except for business type and debt status, job satisfaction, job difficulty compared to education level, work difficulty compared to technology level, and job major agreement.

\subsection{Discussion and suggestion of the research results}

Despite these limitations, this study analyzed the factors related to the preparation for changing jobs among young people using the youth panel data for the 2007-2018, and found that an alternative plan is necessary to understand and resolve the preparation for changing jobs among young people. It was confirmed that factors such as job satisfaction are highly related to turnover preparation for young people with short career in general. Younger people are more concerned about the inherent satisfaction of their jobs in their majors, education levels, and skills in their work lives than the middle-aged. This is related to life-cycle aspects, because a job can be seen as an important development process that represents one's identity. Since jobs can have different meanings depending on age and career, young people with relatively short ages and careers will be affected by the inherent satisfaction factors of their jobs compared to middle-aged people. On the other hand, middle-aged and older people with many work experience and relatively older age may have relatively less relevance to their job characteristics when considering turnover. This is because the higher the age and service life of middle-aged people, the more factors other than their duties, such as family support and investment impact on organizations, affect their will to change jobs.

This study confirmed that young people's turnover may not simply be a means to get a better job, but to increase satisfaction in the internal aspects of their jobs, and that for 
young people, a job is an important development process that represents their identity and needs to be approached from a life-cycle perspective.

The policy implications obtained from this study are as follows. In order to understand the turnover of young people, more intrinsic job satisfaction should be considered. Social conditions, such as youth unemployment and economic recession, appear to be pursuing more such as annual salary and company size. However, such external conditions are difficult to satisfy all people. In the long run, the plan to satisfy the intrinsic aspects of the job will help improve overall job satisfaction and improve job satisfaction. The high turnover rate is also pointed out as an important factor to consider when discussing about youth unemployment. Therefore, it is more necessary to have support policies that take into account both the unemployment rate of young people and the phenomenon of leaving the workforce than simply support policies aimed at reducing the unemployment rate. Understanding that this phenomenon can also be seen as an inherent job dissatisfaction or a productive process of building a better-conditioned job position, education programs should be supported to help young people choose better jobs, their majors and skills.

\section{References}

Behtoui, A. (2004). Unequal opportunities for young people with immigrant backgrounds in the Swedish labour market. Labour, $18,633-660$.

Dicker, D. N., Roznowski, M., \& Harrison, D. A.(1996). Temporal tempering: An event history analysis of the process of voluntary turnover. Journal of Applied Psychology, 81(6), 705-716.

Gardecki, R., \& Neumark, D.(1998). Order from Chaos? The Effects of Early Labor Market Experiences on Adult Labor Market Outcomes. Industrial and Labour Relations Review, 51(2), 299-322.

Hahn, J. H. (2005). Job motivations, job characteristics, workfamily conflict and stress: The case of salesmen in the insurance industry. Journal of Insurance Studies, 16(3), 3 -31

Kim, J. J. (2014). A Study on the Role of the Leader in the Organizational Life for the Social Integration and the Changing Consciousness among the Traders: Focused on traditional market in Seongnam-si, Gyeonggi-do, Gyeonggi-do. Journal of Social Contribution, 1(2). 6-10.

Kim, J. J. (2016). A Study on the Change of Conscious Thinking Process and Moral Reasoning in Social Welfare. Journal of Social Contribution, 3(1), 2-6.

Law, K. S., Wong, C. S., \& Song, L. J. (2004). The Construct and Criterion Validity of Emotional Intelligence and Its Potential Utility for Management Studies. Journal of Applied Psychology, 89(3), 483-496.

McKee, R. F., Song, Z., Wanberg, C. R., \& Kinicki , A. J. (2005). Psychological and physical well-being during unemployment: a meta-analytic study. Journal of applied psychology, 90(1), 53-76.

Mobley, W. H. (1982). Some unanswered questions in turnover and withdrawal research. Academy of management review, 7(1), 111-116.

Price, J. L. (2001). Reflections on the determinants of voluntary turnover. International Journal of Manpower, 22(7), 600-624.

Portes, A., \& Landolt, P. (2000). Social Capital: Promise and Pitfalls of its Role in Development. Journal of Latin American Studies, 32, 529-547.

Saari, L. M., \& Judge, T. A. (2004). Employee Attitudes and Job Satisfaction. Human Resource Management, 43(4), 395-407.

Sanders, J., Nee, V., \& Sernau, S. (2002). Asian Immigrants' Reliance on Social Ties in a Multiethnic Labor Market. Social Forces, 81(1), 281-314.

Song, W., Wangerg, C., Niu, X., Xie, Y. (2006). Action-state orientation and the theory of planned behavior: A study of job search in China. Journal of Vocational Behavior, 68, 490-503.

Topel, R. H., \& Ward, M. P. (1992). Job Mobility and the Careers of Young Men. The Quarterly Journal of Economics, 107(2), 439-479.

Wanberg, C. R., Kanfer, R., \& Banas, J. T. (2000). Predictors and outcomes of networking intensity among unemployed job seekers. Journal of Applied Psychology, 85, 491-503.

Wanberg, C., Glomb, T. M., Song, Z., \& Sorenson, S. (2005). Jobsearch persistence during unemployment: a 10-wave Longitudinal study. Journal of Applied Psychology, 90(3), 411430 . 